\title{
Firm Size, Capital Structure And Earnings Announcement Price Response
}

Joseph H. Anthony, (E-mail: anthony@msu.edu), Michigan State University

\begin{abstract}
The existence of firm size effects is well documented in the accounting and finance literatures. One stream of this research interprets firm size as a proxy for the amount of information available about the firm. This paper extends prior work in this area and demonstrates that the significance of the size effect is increased substantially by considering information demands of both debt and equity investors. A size proxy that includes the book value of outstanding debt is more highly associated with returns surrounding annual and quarterly earnings announcements than a measure based solely on the market value of common equity.
\end{abstract}

\section{INTRODUCTION}

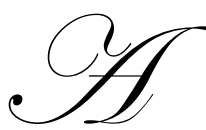

tiase (1985) offers a firm size, differential predisclosure information hypothesis, (hereafter referred to as the Ainformation availability@ hypothesis) which suggests that the stock price response to firms= earnings announcements is inversely related to firm size (where firm size is measured by the market value of common equity). This research flows from a suggestion by Banz (1981) that observed size differences in empirical financial research may be attributable to differences in information availability. Under Atiase $=\mathrm{s}$ hypothesis, private predisclosure information production is an increasing function of firm size. Large firms face a greater demand for firm specific information due to greater incentives for information search. Large firms attract greater investor interest, financial analyst interest, press coverage, and institutional investor following. Therefore, the amount of unexpected information contained in an accounting earnings announcement is inversely related to firm size. This information availability hypothesis suggests that the larger the outside investor interest in a firm, the more likely that share prices will exhibit a smaller response to earnings announcements.

Atiase (1985) offers empirical evidence supporting the information availability hypothesis for second quarter earnings announcements. Grant (1980) offers similar conclusions regarding annual earnings announcements, and also reports significance for an alternative predisclosure information proxy (the number of firm specific news items appearing in the Wall Street journal during the predisclosure period). Grant does not consider size directly, but compares typically larger exchange listed to smaller OTC firms. Atiase (1987) extends his earlier analyses to annual announcements and offers support for both a size effect and an exchange listing effect ${ }^{1}$ in explaining cross-sectional differences in security price response to accounting earnings announcements. Dempsey (1989) provides evidence of a size effect surrounding annual announcements and reports significance for a Anumber of analysts@ variable, which is claimed as a proxy for the amount of predisclosure information.

This paper follows Atiase $=\mathrm{s}$ basic approach in hypothesizing that the market response to earnings may be partially explained by the differential availability of firm-specific, predisclosure information. However, the focus here is on the information demand of all long-term outside investors, rather than just common stockholders. Firms with relatively large balances of outstanding long-term debt (e.g., utilities) and/or preferred stock should generate similar availability of information to an all-equity firm of the same relative size ${ }^{2}$. For example, it is well known that many closely held firms

\footnotetext{
${ }^{1}$ The exchange listing effect is not considered in this study. All sample firms are listed for trading on the NYSE, AMEX or NASDAQ.

${ }^{2}$ Information demands of preferred shareholders or lenders may differ from those of common shareholders. For example, since debt represents a senior security, these outside investors may be less interested in the variance of returns. The information needs of
} 
will produce audited financial statements (and accompanying GAAP disclosures) to comply with covenants of bank lending agreements. Information needs of preferred shareholders could likewise generate an interest in firm-specific information.

If this information availability hypothesis holds, then a measure of firm size which includes information demands of preferred shareholders and bondholders will provide incremental explanatory power for abnormal returns surrounding earnings releases, even after considering a proxy which relies solely on the market value of common shares.

The results presented here indicate that the market value of common equity generally provides a suitable proxy for information availability in explaining cross-sectional differences in the price response to earnings, consistent with prior research. However, when the analysis is limited to firms for which long-term debt represents a more important part of total invested capital, the debt variable provides incremental explanatory power for the observed cross-sectional differences. Thus, the information demand of preferred shareholders and long-term debtholders provides an important, additional controlling variable for accounting research studies comparing firms with varying capital structures.

The following section presents the research design and discusses sample selection. The third section summarizes the results of the empirical tests. Tentative conclusions, limitations, and suggestions for future research are presented in the final section.

\section{RESEARCH DESIGN AND SAMPLE SELECTION}

The study includes both annual and second quarter earnings announcement dates. The annual sample covers the twenty years from 1985 through 2004, while the quarterly sample includes the ten years from 1985 through 2004.

In order to be included in the study, firms must be: (1) listed for trade on the NYSE, AMEX or NASDAQ national exchanges, (2) included on the daily CRSP returns database, (3) included on both the annual and quarterly COMPUSTAT database, (4) have a December 31 fiscal year-end, (5) be a nonfinancial firm (excludes SIC codes 60006999), (6) annual and quarterly announcements available in the Wall Street Journal (WSJ) during any of the test periods, and (7) had no earnings forecasts, merger or divestiture activity, dividend or stock split announcements published in the WSJ during the same calendar week as the earnings announcement.

Necessary book value information and earnings announcement dates are collected from COMPUSTAT and weekly returns are calculated using the CRSP database. Firms with missing CRSP data (more than 20 daily returns during the various estimation periods) or COMPUSTAT data on the variables required for the analyses are eliminated. Firms with a zero total book value for long-term debt plus preferred stock are also eliminated, to better focus on the variables of interest.

Earnings announcement dates are originally obtained from quarterly COMPUSTAT and cross-checked to the WSJ Index. If the WSJ date failed to fall within the same calendar week as the COMPUSTAT date, the firm is eliminated from the sample. If the WSJ Index did not note the earnings announcement, the firm is deleted. The sample data sets include 15,064 annual and 10,496 second quarterly earnings announcements. The samples are each divided into two subsamples of large and small firms, based on rankings of size measured by the natural log of the market value of equity (LMVE). Firms are ranked by LMVE and divided into three equal groups ${ }^{3}$. Firms in the lowest third are classified as small, the highest third are classified as large and the middle third are excluded. The final samples include 10,042 annual

common shareholders and other outside investors may not be linearly related. The issuance of new debt may provide for increased information through various debt covenants. Such information demands may cease to exist when the debt is repaid. These are open empirical questions which this paper addresses only indirectly.

Harris and Raviv (1990) propose that there is an informational role of debt for common shareholders. Under their hypothesis, debt and its related contractual costs serve as a further restriction on the activities of management. These restrictions provide incremental information to common shareholders.

${ }^{3}$ Large and small firm subsamples are defined based on the LMVE variable. An alternative sort based on LDEBT (not tabulated) produces qualitatively similar results. Table 1 presents data for the annual announcements. Quarterly data are qualitatively similar and not tabulated. 
and 6,996 quarterly announcements.

\section{Research Design}

Returns are divided into a non-report and a report period. The report period is the five weeks centered on the earnings announcement date. The non-report period includes a minimum of 104 weeks ended at the start of the report period. The non-report period begins in the third week of December (June for quarterly announcements) two years prior to the announcement date. The length of the non-report period varies, dependent on the announcement date.

Tests performed include associations of the firm size variables with unexpected security returns. Unexpected returns are extracted using the market model, regressing weekly return relatives for individual firms on the weekly market return relatives for the non-report periods. He market model is run using the CRSP value-weighted index. Unexpected returns are calculated as:

$\mathrm{u}_{\mathrm{it}}=\mathrm{R}_{\mathrm{it}}-\left[\mathrm{a}_{\mathrm{i}}+\mathrm{b}_{\mathrm{i}} \mathrm{R}_{\mathrm{mt}}\right]$

where: $u_{i t}=$ unexpected weekly return relative for firm $i$ in week $t$, and

$\mathrm{R}_{\mathrm{it}}, \mathrm{R}_{\mathrm{mt}}=$ realized weekly return relatives for firm $\mathrm{i}$ and the market index, respectively.

\section{Dependent Variable}

Patell=s (1976) Revaluation Index (RI) is used as the dependent variable, and calculated as follows:

$\mathrm{RI}_{\mathrm{it}}=\left[\mathrm{U}_{\mathrm{it}}^{2} / \mathrm{C}_{\mathrm{it}} \mathrm{S}_{\mathrm{i}}^{2}\right] \times[(\mathrm{T}-4) /(\mathrm{T}-2)]$.

Distributional properties of RI are summarized in Atiase (1985: 27-28). The report week RI is a measure of the amount of new information conveyed by the earnings report, relative to the information during the non-report periods. The measure allows each firm to serve as its own endogenous control. $E\left(\mathrm{RI}_{\mathrm{i} 0}\right)=1.0$, therefore, observed $\mathrm{RI}_{\mathrm{i} 0}$ greater than 1.0 indicate that the earnings report conveys new information.

\section{Independent Size Variables}

Independent regression variables are alternative firm size measures (LMVE and LDEBT). Complete variable definitions are provided in Table 1 .

Table 1 also presents summary descriptive statistics for the annual earnings sample ${ }^{4}$. Since distributions of the size variables are highly skewed, natural logs of these variables are used in the analyses. Use of logs reduces the dispersion and minimizes the effects of extreme observations, as can be seen in Table 1.

The size measures are cross-correlated and Pearson correlations are summarized in Table 2. Correlations are high as expected (annual $=.72$ and quarterly $=.69$ ). Larger equity firms are likely to have relatively larger amounts of debt and preferred stock. Covariability appears to present less of a problem for the subsamples of large and small firms. The correlation of LMVE and LDEBT is only .46 and .33 for the small and large firm annual subsamples (.48 and .24 for the quarterly subsamples).

\footnotetext{
${ }^{4}$ Descriptive statistics for the quarterly sample (untabulated) are qualitatively and quantitatively similar.
} 
Table 1

Descriptive Statistics for Annual Sample

\begin{tabular}{|c|c|c|c|c|c|}
\hline Size Variable $^{\mathbf{5}}$ & Mean & STD & Q1 & Q2 & Q3 \\
\hline All firms $(n=10,042)$ & & & 75.55 & 322.33 & 1087.15 \\
\hline MVE & 1053.13 & 1929.23 & 24.56 & 118.33 & 545.85 \\
\hline DEBT & 581.60 & 1223.03 & 4.32 & 5.77 & 6.99 \\
\hline LMVE & 5.66 & 1.78 & 3.20 & 4.77 & 6.30 \\
\hline LDEBT & 4.65 & 2.17 & & & \\
\hline Small firms $(n=5,021)$ & & 19.48 & 40.55 & 75.57 \\
\hline MVE & 49.94 & 35.31 & 6.39 & 20.24 & 49.88 \\
\hline DEBT & 47.51 & 87.03 & 2.96 & 3.70 & 4.32 \\
\hline LMVE & 3.59 & 0.86 & 1.85 & 3.00 & 3.90 \\
\hline LDEBT & 2.77 & 1.68 & & & \\
\hline Large firms $(n=5,021)$ & & 1086.60 & 1790.88 & 3253.37 \\
\hline MVE & 2748.50 & 2603.42 & 238.20 & 700.65 & 1738.29 \\
\hline DEBT & 1385.95 & 1810.28 & 6.99 & 7.49 & 8.08 \\
\hline LMVE & 7.61 & 0.73 & 5.47 & 6.55 & 7.46 \\
\hline LDEBT & 6.34 & 1.58 & & & \\
\hline
\end{tabular}

Variable Definitions

MVE = Market value of common equity,

DEBT $=$ Book value of long-term debt plus preferred equity,

LMVE = Natural of MVE,

and LDEBT $=$ Natural log of DEBT.

Table 2

Pearson Correlations Among Size Variables

\begin{tabular}{|c|c|c|c|}
\hline \multicolumn{4}{|c|}{ Annual Earnings Announcements } \\
\hline & $\begin{array}{c}\text { All Firms } \\
(\mathrm{n}=\mathbf{1 0 , 4 9 2})\end{array}$ & $\begin{array}{c}\text { Small Firms } \\
(n=5,021)\end{array}$ & $\begin{array}{c}\text { Large Firms } \\
(n=5,021)\end{array}$ \\
\hline & LDEBT & LDEBT & LDEBT \\
\hline LMVE & .7231 & .4562 & .3319 \\
\hline p-value & .0001 & .0001 & .0001 \\
\hline \multicolumn{4}{|c|}{ Quarterly Earnings Announcements } \\
\hline & $\begin{array}{l}\text { All Firms } \\
(\mathrm{n}=6,996)\end{array}$ & $\begin{array}{c}\text { Small Firms } \\
(n=3,498)\end{array}$ & $\begin{array}{c}\text { Large Firms } \\
(n=3,498)\end{array}$ \\
\hline & LDEBT & LDEBT & LDEBT \\
\hline LMVE & .6924 & .4792 & .2499 \\
\hline p-value & .0001 & .0001 & .0001 \\
\hline
\end{tabular}

\section{Regression Models}

Both univariate and multivariate models are employed to explore the relation between the market response and the alternative firm size variables. The following models are used for both the annual and quarterly analyses:

Model 1: RI $\mathrm{i}_{0}=\mathrm{b}_{0}+\mathrm{b}_{1} \mathrm{LMVE}_{\mathrm{i}}+\mathrm{e}_{\mathrm{i}}$

Model 2: $\mathrm{RI}_{\mathrm{i} 0}=\mathrm{b}_{0}+\mathrm{b}_{1}$ LDEBT $_{\mathrm{i}}+\mathrm{e}_{\mathrm{i}}$

Model 3: RI $\mathrm{i}_{0}=\mathrm{b}_{0}+\mathrm{b}_{1} \mathrm{LMVE}_{\mathrm{i}}+\mathrm{b}_{2} \operatorname{LDEBT}_{\mathrm{i}}+\mathrm{e}_{\mathrm{i}}$

\footnotetext{
${ }^{5}$ All size variables are based on beginning of the year values.
} 


\section{RESULTS AND DISCUSSION}

Table 3 summarizes observed average $\mathrm{RI}_{\mathrm{it}}$ for both annual and quarterly announcements. As can be seen in the Table, the highest RI is observed during the announcement week, consistent with Atiase $=\mathrm{s}(1985,1987)$ findings. Table 3 also indicates that small firms $\mathrm{RI}=\mathrm{s}$ are higher than those for large firms, again consistent with the Atiase findings.

Table 3

Average Revaluation Indices

\begin{tabular}{|c|c|c|c|c|c|c|}
\hline \multicolumn{7}{|c|}{ Annual Earnings Announcements } \\
\hline & & \multicolumn{5}{|c|}{ Week in Report Period Relative to Report Week } \\
\hline Sample & $\mathbf{n}$ & -2 & -1 & $\mathbf{0}$ & +1 & +2 \\
\hline All firms & 10,042 & .899 & .984 & $1.559 *$ & 1.165 & .989 \\
\hline Small firms & 5,021 & .879 & .977 & $1.976^{*}$ & 1.228 & .957 \\
\hline Large firms & 5,021 & .908 & .961 & 1.265 & 1.114 & .981 \\
\hline \multicolumn{7}{|c|}{ Quarterly Earnings Announcements } \\
\hline & & \multicolumn{5}{|c|}{ Week in Report Period Relative to Report Week } \\
\hline Sample & $\mathbf{n}$ & -2 & -1 & $\mathbf{0}$ & +1 & +2 \\
\hline All firms & 6,996 & .917 & .929 & $1.526^{*}$ & 1.112 & 1.114 \\
\hline Small firms & 3,498 & .878 & .931 & $1.657 *$ & 1.139 & 1.123 \\
\hline Large firms & 3,498 & .957 & .927 & 1.389 & 1.084 & 1.104 \\
\hline
\end{tabular}

* Indicates significantly greater than the mean at less than the .01 level.

Average report week RIs across all firms are 1.559 and 1.526, respectively, for annual and quarterly announcements. Given an expected value of 1.00, report weeks contain 55.9\% and 52.6\% more information than other weeks in the RP (significant at the .01 level). Results for small firms are similar. The average report week RI is 1.976 for annual announcements ( 1.657 for quarterly announcements), again significantly greater than the average RI of the RP at the .01 level. The large firms also generate increased RI during the report week, but these are not significantly greater than 1.00 .

\section{Regression Results}

\section{Annual Earnings Announcements}

Table 4 summarizes results surrounding annual announcements. As shown in Panel A, univariate analyses (Models 1 and 2) generate significant, negative coefficients as expected. Based on these results, there is a significant inverse relation between $\mathrm{RI}_{\mathrm{i} 0}$ and size, regardless of the firm size proxy employed (LMVE or LDEBT). ${ }^{6}$

The LMVE results are consistent with annual findings reported by Atiase (1987) and with second quarter results reported by Atiase (1985).

Table 4 presents Model 3 multivariate results for the regression of $\mathrm{RI}_{\mathrm{i} 0}$ on both LMVE and LDEBT. The coefficient for LMVE remains positive and highly significant. However, the LDEBT coefficient is no longer significant. The linear explanatory power of LDEBT appears subsumed by the equity size measure.

\footnotetext{
${ }^{6}$ Initial inspection of the firm size measures (LMVE and LDEBT) indicates moderate growth (i.e., nonstationarity) over time. For example, in the annual sample, mean LMVE grows from 5.38 to 5.83 over the test period, and mean LDEBT grows from 4.35 to 4.74. Following Dempsey (1989), the size measures are standardized (individual firm values are divided by annual sample median values) to facilitate intertemporal comparisons. This transformation of the data provides no qualitative differences in results and is excluded from presentation here.
} 
Table 4

Annual Earnings Announcement Regression Results Firms Sorted by LMVE

\begin{tabular}{|c|c|c|c|c|c|}
\hline Model & $\mathbf{b}_{0}$ & $\mathbf{b}_{1}$ & $\mathbf{b}_{2}$ & Adjusted R ${ }^{2}$ & F-Ratio \\
\hline \multicolumn{6}{|c|}{ Panel A: All firms $(n=10,042)$} \\
\hline 1 & 2.891 & -0.227 & & .01 & 22.562 \\
\hline t-statistics & $10.09 * * *$ & $-4.75 * * *$ & & & .0001 \\
\hline 2 & 2.397 & -0.170 & & .01 & 15.914 \\
\hline t-statistics & $10.89 * * *$ & $-3.99 * * *$ & & & .0001 \\
\hline 3 & 2.880 & -0.201 & -0.029 & .01 & 11.369 \\
\hline t-statistics & $10.01 * * *$ & $-2.61 * * *$ & -0.43 & & .0001 \\
\hline \multicolumn{6}{|c|}{ Panel B: Small firms $(n=5,021)$} \\
\hline 1 & 5.513 & -0.983 & & .01 & 17.623 \\
\hline t-statistics & $6.36 * * *$ & $-4.20 * * *$ & & & .0001 \\
\hline 2 & 2.637 & -0.238 & & .01 & 3.887 \\
\hline t-statistics & $6.73 * * *$ & $-1.97 * *$ & & & .0488 \\
\hline 3 & 5.509 & -0.974 & -0.010 & .01 & 8.809 \\
\hline t-statistics & $6.34 * * *$ & $-3.70 * * *$ & -0.07 & & .0002 \\
\hline \multicolumn{6}{|c|}{ Panel C: Large firms $(n=5,021)$} \\
\hline 1 & 0.650 & .081 & & .01 & 2.492 \\
\hline t-statistics & $1.66^{*}$ & 1.58 & & &. .1146 \\
\hline 2 & 1.390 & -0.020 & & .00 & 0.694 \\
\hline t-statistics & $8.96 * * *$ & $-0.83)$ & & & .4051 \\
\hline 3 & 0.682 & -0.107 & -0.036 & .01 & 2.283 \\
\hline t-statistics & $1.174^{*}$ & $-1.97 * *$ & -1.44 & & .1023 \\
\hline
\end{tabular}

$*, * *, * * *$ - Indicates t-statistic significant at the $.10, .05$ and .01 levels.

Panels B and C offer results for the small and large firm subsamples, respectively. The small firm results in Panel B are essentially identical to those in Panel A. The size measures both indicate significance in the univariate analyses, but only LMVE is significant in the multivariate analysis (Model 3).

Panel C results for the large firms differ markedly from those reported in Panels A and B. None of the univariate models generate significant coefficients for the size measures. The LMVE coefficient is significant in the multivariate analysis. This result is again generally consistent with Atiase (1985).

Firms in Table 4 regressions are classified as large or small based on the value of LMVE, which may induce a bias toward significance for that size measure. Table 5 reports additional results to provide some insight into the extent of potential bias in Table 4. Classification of firms as large or small is repeated based on LDEBT. As shown in Table 5, the reclassification does not qualitatively alter the Table 4 results.

Table 5

Annual Earnings Announcement Regression Results Firms Sorted by LDEBT

(All Firms: $n=10,042$ )

\begin{tabular}{|c|c|c|c|c|c|}
\hline Model & $\mathbf{b}_{\mathbf{0}}$ & $\mathbf{b}_{\mathbf{1}}$ & $\mathbf{b}_{\mathbf{2}}$ & Adjusted R & F-Ratio \\
\hline 1 & 3.243 & -0.281 & & .01 & 28.336 \\
\hline t-statistics & $10.25^{* * *}$ & $-5.32^{* * * *}$ & & & .0001 \\
\hline 2 & 2.355 & -0.153 & & .01 & 14.807 \\
\hline t-statistics & $11.20^{* * *}$ & $-3.85^{* * *}$ & & & .0001 \\
\hline 3 & 3.285 & -0.315 & -0.032 & .01 & 14.291 \\
\hline t-statistics & $10.04^{* * *}$ & $-3.70^{* * *}$ & -0.50 & & .0001 \\
\hline
\end{tabular}

$*, * *, * * *$ - Indicates t-statistic significant at the $.10, .05$ and .01 levels. 
Overall, the results in Tables 4 and 5 appear to indicate that the market value of common equity provides a sufficient control variable for the firm size effect.

\section{Annual Analyses Limited To Firms With Large Debt Balances}

Table 6 reports the results of additional regressions to further investigate the information demands of preferred shareholders and long-term debtholders. In Panel A, firms are first sorted into deciles, separately, based on LMVE and LDEBT. Those firms ranked in a higher decile for LMVE than for LDEBT are eliminated. Remaining firms are those for which LDEBT represents a proportionately larger share of the total capital structure. For those firms, the results are somewhat different.

Table 6

Annual Earnings Announcement Regression Results Model: $\mathbf{R I}_{\mathrm{i} 0}=\mathrm{b}_{0}+\mathrm{b}_{1} \mathrm{LMVE}_{\mathrm{i}}+\mathrm{b}_{2} \mathrm{LDEBT}_{\mathrm{i}}+\mathrm{e}_{\mathrm{i}}$

\begin{tabular}{|c|c|c|c|c|}
\hline $\mathbf{b}_{\mathbf{0}}$ & $\mathbf{b}_{\mathbf{1}}$ & $\mathbf{b}_{\mathbf{2}}$ & Adjusted R $^{\mathbf{2}}$ & F-Ratio \\
\hline \multicolumn{5}{|c|}{ Panel A: Sorted by LMVE - Excludes firms with equity ranked higher than debt (n = 5,260) } \\
(t-statistics in parentheses) & .01 & 10.603 \\
\hline 4.164 & -0.545 & -0.222 & $(1.79)^{*}$ & $.0001)$ \\
\hline$(7.54)^{* * *}$ & $(-3.67)^{* * *}$ & Panel B: Sorted by DER - Excludes firms with large DER (n = 5,021) \\
(t-statistics in parentheses) & .01 & 9.362 \\
\hline 3.966 & 0.136 & -0.539 & $(.0001)$ \\
\hline
\end{tabular}

$*, * *, * * *$ - Indicates t-statistic significant at the $.10, .05$ and .01 levels.

The univariate regression results (untabulated) continue to exhibit significant coefficients for both LMVE and LDEBT. However, when the multivariate regression is run, the results indicate significant coefficients for both variables. The linear explanatory power of LDEBT is no longer subsumed by LMVE. Thus, for firms with relatively more important debt and preferred shares in the capital structure, the LDEBT variable provides incremental explanatory power.

Results in Panel B again attempt to isolate firms where debt and preferred stock represent a greater portion of total invested capital. Here, firms are ranked by their debt to equity ratios (DER). DER is calculated as DEBT / MVE, and does not represent a traditional debt to equity calculation. Instead, the ratio considers both long-term debt and preferred shares in relation to total capital investment. Panel B reports results for firms having the highest DER (as in prior sorts, firms are ranked from highest to lowest, with the middle $1 / 3$ eliminated). Using this approach, univariate regressions still indicate significance for both size measures, but in the multivariate model, it is the LMVE variable whose explanatory power is now subsumed by the LDEBT measure.

\section{Quarterly Earnings Announcements}

Tables 7 and 8 provide summarized results for the quarterly announcement tests. Overall, the quarterly results mirror those for annual announcements. Coefficients for the univariate regressions (not tabulated) are negative and highly significant, both for the total sample and the two size subsamples. Table 7 reports multivariate regression results, using the alternative size measures to classify firms as large or small. As is true for the annual earnings announcements in Tables 4 and 5, the LMVE coefficient is negative and highly significant, while the LDEBT coefficient is insignificant. This result holds, regardless of the size measure used to classify firms as small or large. As with annual announcements, it appears that the linear explanatory power of LDEBT is subsumed by the LMVE firm size measure. 
Table7

Quarterly Earnings Announcement Regression Results

(All Firms $n=6,996$ )

Model: RI $_{i 0}=b_{0}+b_{1} L_{M V E}+b_{2} L$ DEBT $_{i}+e_{i}$

\begin{tabular}{|c|c|c|c|c|}
\hline$b_{0}$ & $\mathbf{b}_{1}$ & $\mathbf{b}_{2}$ & Adjusted $\mathbf{R}^{2}$ & F-Ratio \\
\hline \multicolumn{5}{|c|}{$\begin{array}{l}\text { Panel A: Sorted by LMVE } \\
\text { (t-statistics in parentheses) }\end{array}$} \\
\hline 2.008 & -0.109 & 0.026 & .01 & 4.641 \\
\hline$(11.64)^{* * *}$ & $(-2.41)^{* *}$ & $(0.63)$ & & $(.0097)$ \\
\hline \multicolumn{5}{|c|}{$\begin{array}{c}\text { Panel B: Sorted by LDEBT } \\
\text { (t-statistics in parentheses) }\end{array}$} \\
\hline 2.098 & -0.146 & 0.056 & .01 & 3.448 \\
\hline$(9.03)^{* * *}$ & $(-2.46) * *$ & $(1.26)$ & & $(.0320)$ \\
\hline
\end{tabular}

$*, * *, * * *$ - Indicates t-statistic significant at the $.10, .05$ and .01 levels.

Table 8, Panel A replicates Table 6 results, using the quarterly data, and limiting the sample to those firms ranked higher for LDEBT than for LMVE. Once again, the quarterly results mirror the annual announcement results. Both LMVE and LDEBT provide significant explanatory power. In Panel B of Table 8, LDEBT provides significant incremental explanatory power, similar to the Panel A results. This result differs from annual results in Table 6 in that both variables are significant in the multivariate model, when firms are classified based on DER.

Table 8

Quarterly Earnings Announcement Regression Results Model: $\mathbf{R I}_{\mathrm{i} 0}=\mathbf{b}_{0}+\mathrm{b}_{1} \mathrm{LMVE}_{\mathrm{i}}+\mathrm{b}_{2} \mathrm{LDEBT}_{\mathrm{i}}+\mathrm{e}_{\mathrm{i}}$

\begin{tabular}{|c|c|c|c|c|}
\hline $\mathbf{b}_{0}$ & $\mathbf{b}_{1}$ & $\mathbf{b}_{2}$ & Adjusted R ${ }^{2}$ & F-Ratio \\
\hline \multicolumn{5}{|c|}{$\begin{array}{c}\text { Panel A: Sorted by LMVE - Excludes firms with equity ranked higher than debt }(\mathbf{n}=\mathbf{3 , 2 6 3 )} \\
(\mathrm{t} \text {-statistics in parentheses) }\end{array}$} \\
\hline 2.520 & -0.250 & -0.124 & .01 & 5.835 \\
\hline$(8.22)^{* * *}$ & $(-3.02) * * *$ & $(1.75)^{*}$ & & $(.0030)$ \\
\hline \multicolumn{5}{|c|}{$\begin{array}{l}\text { Panel B: Sorted by DER - Excludes firms with large DER }(n=\mathbf{3 , 4 9 8}) \\
\text { (t-statistics in parentheses) }\end{array}$} \\
\hline 2.052 & -0.163 & -0.104 & .01 & 3.015 \\
\hline$(7.51)^{* * *}$ & $-(2.43) * *$ & $(1.79)^{*}$ & & $(.0494)$ \\
\hline
\end{tabular}

$*, * *, * * *$ - Indicates t-statistic significant at the $.10, .05$ and .01 levels.

\section{SUMMARY AND CONCLUDING REMARKS}

Prior research notes the existence of a firm size effect in explaining the relation between earnings announcements and security market response. A general conclusion from these studies is that research designs should include a conditioning variable for this effect. Atiase (1985, p.35) notes A...future empirical research designs requiring control for (private) predisclosure information should control for the capitalized value of sample firms. This is particularly important for studies aimed at testing the Aeconomic consequence@ and/or Aeffectiveness@ of new public information disclosure rules. $@$ If one accepts that the quality of the proxy can be evaluated by its relation with unexpected returns, then the results presented here indicate that an additional size measure which includes information demands of preferred shareholders and bondholders better proxies for the firm size effect than a measure based solely on the market value of common equity. The additional size measure provides significant incremental explanatory power, even after consideration of the market value of common equity. 
The results presented here suggest that in studies comparing firms with different capital structures, an additional conditioning variable based on the book values of debt and preferred shares should be included. In fact, most accounting information content and economic consequences studies involve such comparisons. For example, King (1966) notes significance for an industry variable in explaining cross-sectional differences in abnormal returns. The industry effect may be due, in part, to capital structure differences across industries. Foster (1986, pp.187-189) documents considerable variation in capital structure (and other financial statement ratios) across industries. Debt to equity ratios for a sample of twelve industries range from 0.04 to 1.41 based on 1983 COMPUSTAT data. As securities markets become more global, researchers will also face potential inference problems due to international capital structure differences.

\section{REFERENCES}

1. Atiase, R.K. 1985. Predisclosure information, firm capitalization, and security price behavior around earnings announcements. Journal of Accounting Research (Spring): 21-36.

2. Atiase, R.K. 1987. Market implications of predisclosure information: size and exchange effects. Journal of Accounting Research (Spring): 168-176.

3. Banz, R. 1981. The relationship between return and market value of common stocks. Journal of Financial Economics 9 (March): 3-18.

4. Beaver, W. 1968. The information content of annual earnings announcements. Journal of Accounting Research (Supplement): 67-92.

5. Dempsey, S.J. 1989. Predisclosure information search incentives, analyst following, and earnings announcement price response. The Accounting Review (October): 748-757.

6. $\quad$ Foster, G. 1986. Financial Statement Analysis. 2nd edition Prentice-Hall: Englewood Cliffs, NJ.

7. Grant, E. 1980. Market implications of differential amounts of interim information. Journal of Accounting Research (Spring): 255-268.

8. Harris, M. and A. Raviv. 1990. Capital structure and the informational role of debt. Journal of Finance (June): 321-349.

9. King, B. 1966. Market and industry factors in stock price behavior. Journal of Business (January): 139-190.

10. Patell, J. 1976. Corporate forecasts of earnings per share and stock price behavior: Empirical tests. Journal of Accounting Research (Autumn): 246-276. 


\section{NOTES}

